\title{
The Effect of Citric Acid Supplementation on Growth Performance, Digestibility and Linear Body Measurement of Ross 308 Broiler Chickens: A Review
}

V. Makofane, J.W. Ng'ambi, B. Gunya

10.18805/IJAR.BF-1433

\begin{abstract}
Feed additives are considered to be one of the most valuable but expensive ingredients in poultry production to optimize high production. The present paper reviews the potential use of citric acid as a cheap and alternative antibiotic growth promoter (AGP) supply in poultry diets. A review was conducted using PubMed/MEDLINE (published articles) to determine the effect of citric acid supplementation on growth performance, digestibility and linear body measurements of Ross 308 broiler chicken. Studies shows that supplementing the diets of broiler chickens with citric acid improves nutrient retention, mineral adsorption, meat attributes, enhance intestinal enzyme activities and protect livestock animals and poultry from harmful microorganisms. Additional notable advantages of acidifiers include the potential to be used to favourably alter gut flora populations and stimulate immunological response and so serve a function similar to antibiotic-resistant strains of harmful bacteria in food animals. Citric acid also promotes nutrient digestion and mineral absorption. The inclusion of organic acids ultimately results in the thickening of the intestinal wall, which promotes in the improved absorption of nutrients and the efficient utilization of those nutrients.
\end{abstract}

Key words: Citric acid, Digestibility, Growth performance, Linear measurements.

Amongst the most significant challenges plaguing the poultry industry mostly boilers need more focus in order to minimize pathogen effects on human and animal health (Marshall and Levy, 2011; Moyane et al., 2013; Calicioglu et al., 2019).

Antibiotics, antifungals, antivirals, antimalarials and anthelmintics, for example, have raised levels of tolerance in bacteria, parasites, viruses and fungi (FAO, 2017). Antibiotic growth promoters have been used in broilers to optimize live weight and feed efficiency (virginiamycin, linomycin, sacox, avilamycin, flavomycin and others) (Diaz Carrasco et al., 2019). However, there are consumer fears that their addition in the feed may promote resistant strains of pathogens against those antibiotics (Paiva and McElroy, 2014; Dittoe et al., 2018). Antibiotic growth promoters such as avoparcin, enrofloxacin and tylosin triggered the production of a resistant pathogen in the human population through the consumption of animal-derived food (Bozkurt et al., 2008; Cogliani et al., 2011; Ao et al., 2012). Furthermore, the use of antibiotic performance enhancers (APE), as well as the clinical use of anticoccidials and chemotherapy, has been shown to be particularly harmful to birds. Since 2006, the European Union has prohibited the use of antibiotics as growth promoters and North America has followed suit. This is due to the significant danger of antimicrobial resistance (Khan and lqbal, 2015; Pritchard, 2016).

Alternative forms of growth promoters for poultry, such as organic acid, have been investigated systematically. These alternatives provide some adequate essential and non-essential elements to stimulate growth (M'Sadeq et al., 2015). Furthermore, Mohyla et al. (2007) observed that the
Department of Agricultural Economics and Animal Production, University of Limpopo, Sovenga, 0727, South Africa.

Corresponding Author: B. Gunya, Department of Agricultural Economics and Animal Production, University of Limpopo, Sovenga, 0727, South Africa. Email: Busisiwe.Gunya@ul.ac.za

How to cite this article: Makofane, V., Ng'ambi, J.W. and Gunya, B. (2022). The Effect of Citric Acid Supplementation on Growth Performance, Digestibility and Linear Body Measurement of Ross 308 Broiler Chickens: A Review. Indian Journal of Animal Research. DOI: $10.18805 /$ IJAR.BF-1433.

Submitted: 03-09-2021 Accepted: 13-01-2022 Online: 03-03-2022

usage of citric acid might promote the growth of broiler chickens while simultaneously decreasing mortality. Citric acid supplementation has been explored to be an effective feed additive for broiler growth (M'Sadeq et al., 2015, Dittoe et al., 2018, Al-Amri and Al-Jasham, 2019). Thus, the chemical properties of citric acid enable it, to be supplemented in water for chickens and pigs, to enhance growth (M'Sadeq et al., 2015). There is limited information on properties of citric acid along with its nutritive potential and utilization as feed additive in chickens feed components that is comprehensive in South Africa. Thus, the purpose of this review is to raise awareness about the nutritional value and potential growth promoter properties of citric acid as a source of growth promoter for chicken.

\section{Description of citric acid}

The citric acid found in citric fruits is a weak organic acid (Islam et al., 2008). Citrus fruits (lemons, oranges, grapes 
and so on) are categorized as acid fruits because they contain sufficient amount of citric acid (Max et al., 2010). Citric acid is an extremely flexible organic acid that is frequently applied in the drug industry (Islam et al., 2008). Pigs and chickens have widely given citric acid as an organic acid supplement (Kim et al., 2015, Lakshmi and Sunder, 2015, Diaz et al., 2019). Haščík et al. (2019) reported that citric acid is mostly utilized as an acidifier and flavouring ingredient. This organic compound is a natural preservative that is frequently used to give food and soft drinks an acidic or sour taste (Pelletier and Lawless, 2003; Bagal et al., 2016). It exhibits adequate antimicrobial activity to inhibit bacterial spoilage while also reducing harmful bacteria in the gastrointestinal tract (example, E. coli.) (Archana et al., 2019) and ultimately improves the growth rate of different animal species to an extent comparable to antimicrobial growth promoters (Llor and Bjerrum, 2014).

\section{Citric acid as a growth promoter}

Early therapeutic acidifier exposure in birds can elicit adaptive response, minimizing the antimicrobial activity and, as a result, enhancing the birds' development efficiency (Islam et al., 2008). In order to limit the economic losses due to heat pressure, it is therefore essential to supplement or expose the use of acidifiers in the initial phase instead of the growing one. Archana et al. (2019) indicated that decreased $\mathrm{pH}$ in the intestines with added citric acid may regulate the release of enzymes such as pepsin and phytase that have an impact on the gastrointestinal tract. Citric acid promotes the utilisation of protein and certain minerals (Nourmohammadi et al., 2011; AL-harthi and Attia, 2015). The lower $\mathrm{pH}$ makes the gastro-intestinal tract (GIT) conditions unfavourable to pathogenic bacteria and stimulates the growth of 'healthy' bacteria, leading to high digestion and utilization within the GIT (Mansoub et al., 2011).

\section{Effect of citric acid on growth performance}

\section{Effect of citric acid on feed intake}

The citric acid in high doses reduces feed palatability, while low concentrations enhance feed consumption and thus increase growth in avian species (Haščík et al., 2019). This might be due to the fact that lower $\mathrm{pH}$ leads to a simultaneous increase in favorable bacteria and a substantially higher $\mathrm{pH}$, impede the development of pathogenic bacteria. The inclusion of 0.25 per cent citric acid in the mesh diet reduced consumption (Mohammed, 2018). Mohammadagheri et al. (2016) discovered that citric acid (1.0 per cent) had no influence on feed consumption. A similar effect was reported when 0.5 per cent citric acid was added to the diet (Islam, 2008; Ghazalah et al., 2011). Moreover, Rahman et al. (2018) revealed that the inclusion of 0.75 per cent citric acid to the broiler diet had a significant positive impact on the broilers' feed consumption. This could be because an acidic gastric environment promotes peptide-2, which may aid glucose and protein absorption. Moghadam et al. (2006) reported that supplementing broilers with citric acid (1.5 percent and 3.0 per cent) had a positive effect on feed intake and consumption. A study performed by Atapathu and Nelligaswatta (2005) found that broiler chicks fed a ricebased diet containing 2.0 per cent CA increased their feed consumption significantly (Ao et al., 2009). Citric acid supplementation in the diet had no effect on feed intake in broilers at 21 and 42 days of age (Waseem Mirza et al., 2016).

\section{Effect of citric acid on body weight gain}

Nezhad et al. (2007) observed that inclusion of citric acid $(0.0,2.5 \%$ and $5 \%)$ in water showed a significant effect in broilers on maize soyabean meal-based diet and improved the live weight gain and the effect of the interaction between $\mathrm{CA}$ and microbial phytase showed significant improvement on live weight gain (Islam, et al., 2008; Islam, 2012; Kalafova et al., 2014; Shah et al., 2018). Furthermore, the administration of citric acid ( $0.3,0.5$ and 0.7 per cent) exhibited the best results in terms of improvement in live weight increase when compared to other treatments (Shen et al., 2005; Islam et al., 2008; Mohammed, 2018). Improved performance can be attributed to competitive inhibition of food-borne pathogens, increased nutrient uptake, growth and feed effectiveness and a decrease in viable bacterial cells. Adding CA, ascorbic acid and vitamin D3 to a low calcium diet in broilers increased their body weight by 18 percent, but they had insignificant growth performance when they were fed CA ( 1 and 2 per cent) with rice by-productbased diets, according to Afsharmanesh and Pourreza (2005). This distinction may be attributable to the fact that the birds' response to organic acid supplementation is dependent on the kind and concentration of the acids, the content of meal, the animals' age and health status (Jensen et al., 2003).

\section{Effect of citric acid on feed conversion efficiency}

Organic acid addition is a significant step toward greater efficiency without the use of drugs, which may leave impurities in the meat and increase the danger of antimicrobial resistance (Kim et al., 2015). The reduction in $\mathrm{pH}$ in the GIT promotes a variety of enzymes, including pepsinogen and other zymogens, by attempting to bring the extracellular $\mathrm{pH}$ closer to the optimum value required for optimal action (Afsharmanesh and Pourreza, 2005). Steadily increasing pepsinogen activity results in increased proteolysis, which produces a variety of peptides that trigger the release of cholecystokinin and gastrin (Adil et al., 2010; Samanta et al., 2010). The phenomena of supplementation with citric acid ( 0.3 per cent) ensures the effective broiler chick feed conversion in comparison to those on a control diet (Shen et al., 2005). This could be due to a direct effect of the crop's reduced $\mathrm{pH}$, as the enzyme operates optimally at a $\mathrm{pH}$ of +4.5 . Numerous trials demonstrated a similar effect, with feed conversion efficiency increasing on diets supplemented with three different concentrations of citric acid (0.0, 2.5 and 5.0 per cent), as well as a significant impact 
of the variety of citric acid and microbial phytase on feed conversion efficiency in broilers (Nezhad et al., 2007; Islam., 2012; Haq et al., 2017). Additionally, Kopeck et al. (2012) found that treatment with CA (0.25 per cent) enhanced the feed conversion ratio in broilers. However, the findings are contrary to the study by Mohammed (2016) who observed no effect with the supplementation of CA $(0.25 \%)$. Atapattu and Nelligaswatta (2005) concluded that supplementation of citric acid ( 1.0 and $2 \%$ ) has no effect on feed conversion ratio in broiler chicken-fed rice by product-based diet. This variation could be attributed to the introduction of acidic environments to gut, which triggers the release of pepsin, gastrin and cholecystokinin, which together play important roles in feed conversion and hence improve growth performance (Hayat et al., 2014).

\section{Effect of citric acid on body linear measurements}

Mohammed (2016) noted that using citric acid as a supplement for broilers boosted back fat and had no effect on breast meat yield in terms of weight. Acidification had no influence on breast, thigh, or giblet weight (Haq et al., 2014). The head, wing, back, thigh and breast showed the most improvement (Islam et al., 2008). Mohammed (2018) found that adding citric acid to mesh diets improved the thigh, breast, back, wings, head, shank and skin the most. This contrasts with Kopeckı et al. (2012) assessment that the carcass yields, percentages of breasts and thighs and average abdominal fat weights with citric acid are not affected. This contrast may be due to nutrition, location and various breeds used.

\section{Effect of citric acid on digestibility}

All modifications to the GIT will have an impact on the digestion and nutrient utilization of the diet. Citric acid degrades the structure of crude fiber, increasing the susceptibility of crude protein and comparable phytate to enzymatic digestion and hence nutrient digestibility (Lückstädt and Mellor, 2011). Citric acids do not have any residual or detrimental residue in meat products, as well as the lack of any environmental impact contributing to microbial resistance, as is the case with antibiotics. Vargas-Rodriguez et al., (2002), Ao et al, (2009) and Haq et al. (2017) discovered that 2 percent citric acid in the broiler feed improves DM, CP and neutral detergent substance absorption. Moreover, Ghazala et al. (2011) discovered that providing $2 \%$ citric acid to broiler ration improved crude protein $(C P)$, ether extract $(E E)$, crude fiber $(C F)$ and nitrogen-free extract (NFE). Nonetheless, Mohammadagheri et al. (2016) found that supplementing broilers with citric acid $(1.0 \%)$ had no effect on digestion. These could be attributed to management techniques and breed, physiological age, different diet and citric acid dose which ultimately change the gastrointestinal $\mathrm{pH}$ thus resulting in poor absorption of nutrients and utilization these indirectly affect digestion. Dietary salinity promotes gut proteolysis and digestion (Cogliani et al., 2011). Broilers added citric acid had longer and thicker villi than controls and thus a better digestive and feed absorbance efficiency (AbdelFattah et al., 2008). Citric acid at (4 to 6\%) added to broiler water, resulted in lower crude protein $(\mathrm{CP})$ utilization is lower than that of control (Islam. 2012; Nourmohammadi and Khosravinia 2015). Furthermore, CA supplements of 1.0 and 2.0 per cent improved $P$ and $C P$ utilization in broilers (Attapatu et al., 2005; Ghazalah et al., 2011; Ragab et al., 2012; Shah et al., 2018). Optimized digestive and absorptive abilities of chickens fed organic acid-supplemented diets have been extensively demonstrated and it can thus be concluded that organic acids have a beneficial influence on nutrient utilization of the birds, increasing overall flock effectiveness and efficiency.

\section{Limitation of citric acid in chickens}

The limitation to the use of citric acid as an organic growth promoter is that higher doses of organic acid might cause harmful effects in the animal and it could be detrimental for the birds as well (Hajati, 2018). Moreover, a higher dose affects the performance of the broiler (Lückstädt and Mellor, 2011). Various parameters, such as dietary contents, proximity to feeding and/or drinking, environmental impacts, other management techniques and even the individual bird itself; breed, physiological age and health status, can all have an impact on the outcomes. Furthermore, most of the tests using organic acids as additive in broiler feeds were carried out under less stressful conditions, which could reflect why the results were uneven.

\section{CONCLUSION}

In essence, CA appears to be a viable supplement that could be utilized as a replacement to antibiotic growth promoters. Improvements in growth performance, intake, feed conversion efficiency, carcass quality, linear measurements and ensuing financial benefits through commercial production are all factors to consider when using it in broiler diets. It is thought to be safe to utilize up to $6 \% \mathrm{CA}$ in broiler diets without impairing performance. Citric acid can serve as a catalyst for performance losses in poultry fed low protein and energy diets, as well as significantly increase mineral availability to the birds. Citric acid has a measurable effect on growth performance, digestibility and linear body measurement in Ross 308 broiler chickens, hence, it is critical to determine the full extent of these impacts.

Conflict of interest: None.

\section{REFERENCES}

Abdel-Fattah, S.A., El-Sanhoury, M.H., El-Mednay, N.M. and AbdelAzeem, F. (2008). Thyroid activity, some blood constituents, organs morphology and performance of broiler chicks fed supplemental organic acids. International Journal of Poultry Science. 7: 215-222.

Adil, S., Banday, T., Bhat, G.A., Mir, M.S., Rehman, M. (2010). Effect of dietary supplementation of organic acids on performance, intestinal histomorphology and serum biochemistry of broiler chicken. Veterinary Medicine International. 2010: 1-7. 
Afsharmanesh, M. and Pourreza, J. (2005). Effects of calcium, citric acid, ascorbic acid, vitamin D 3 on the efficacy of microbial phytase in broiler starters fed wheat-based diets I. Performance, bone mineralization and ileal digestibility. Asian Network for Scientific Information. 4: 418-424.

Al-Amri, Z.A.A. and Al-Jashami, S.M. (2019). Effect of adding citric acid and tartaric acid to the diet on productive performance for broiler chickens (Ross-308). Euphrates Journal of Agriculture Science. 11:19-29.

Al-Harthi, M.A. and Attia, Y.A. (2015). Effect of citric acid on the utilization of olive cake diets for laying hens. Italian Journal of Animal Science. 14: 39-66.

Ao, T., Cantor, A.H., Pescatore, A.J., Ford, M.J., Pierce, J.L. and Dawson, K.A. (2009). Effect of enzyme supplementation and acidification of diets on nutrient digestibility and growth performance of broiler chicks. Poultry Science. 88: 111-117.

Ao, Z., Kocher, A. and Choct, M. (2012). Effects of dietary additives and early feeding on performance, gut development and immune status of broiler chickens challenged with Clostridium perfringens. Asian-Australasian Journal of Animal Sciences. 25: 541.

Archana, K., Zuyie, R. and Vidyarthi, V.K. (2019). Effects of dietary addition of organic acid on performance of broiler chicken. Livestock Research International. 7: 71-76

Atapattu, N.S.B.M. and Nelligaswatta, C.J. (2005). Effect of citric acid on the performance and utilization of phosphorous and crude protein in broiler chickens fed rice by products bassed diets. International Journal of Poultry Science. 4: 990-993.

Bagal, V.L., Khatta, V.K., Tewatia, B.S., Sangwan, S.K. and Raut, S.S. (2016). Relative efficacy of organic acids and antibiotics as growth promoters in broiler chicken. Veterinary World. 9: 377.

Bozkurt, M., Küçükyilmaz, K., Çatli, A.U. and Çinar, M. (2008). Growth performance and slaughter characteristics of broiler chickens fed with antibiotic, mannan oligosaccharide and dextran oligosaccharide supplemented diets. International Journal Poultry Science. 7: 969-977.

Cogliani, C., Goosens, H. and Greko, C. (2011). Restricting Antimicrobial Use in Food Animals: Lessons from Europe. Microbe. 6: 6.

Calicioglu, O., Flammini, A., Bracco, S., Bellù, L. and Sims, R. (2019). The future challenges of food and agriculture: An integrated analysis of trends and solutions. Sustainability. 11: 222.

Diaz Carrasco, J.M., Casanova, N.A. and Fernández Miyakawa, M.E. (2019). Microbiota, gut health and chicken productivity; What is the connection? Microorganisms. 7: 374.

Dittoe, D.K., Ricke, S.C. and Kiess, A.S. (2018). Organic acids and potential for modifying the avian gastrointestinal tract and reducing pathogens and disease. Frontiers in Veterinary Science. 5: 216.

Food and Agriculture Organisation. (2017). The future and agricultureTrends and challenges. Rome.

Ghazalah, A.A., Atta, A.M., Elkloub, K., Moustafa, M.E.L. and Riry, F.H.S. (2011). Effect of dietary supplementation of organic acids on performance, nutrients digestibility and health of broiler chicks. International Journal of Poultry Science. 10: $176-184$.
Hajati, H. (2018). Application of organic acids in poultry nutrition. International Journal Avian Wildlife Biology. 3: 324-329.

Haq, A., Ch, M.T., Ahmad, H., Shafi, J., Ashraf, M., Javed, M. Rehman, S. (2014). Effect of dietary acidification with citric acid on carcass characteristics, haemogram and serum metabolite values of broiler chicken. Pakistan Journal of Life and Social Sciences. 12: 36-41.

Haq, Z., Rastogi, A., Sharma, R. K. and Khan, N. (2017). Advances in role of organic acids in poultry nutrition: A review. Journal of Applied and Natural Science. 9: 2152-2157.

Haščík, P., Pavelková, A., Arpášová, H., Čuboň, J., Kačániová, M. and Kunová. S. (2019). The effect of bee products and probiotic on meat performance of broiler chickens. Journal of Microbiol Biotech Food Science. 9: 88-92.

Hayat, T., Sultan, A., Khan, R.U., Khan, S., Ullah, R. and Aziz, T. (2014). Impact of organic acid on some liver and kidney function tests in Japanese quails, Coturnix coturnix japonica. Pakistan Journal of Zoology. 46(4).

Islam, M.Z., Khandaker, Z.H., Chowdhury, S.D. and Islam, K.M.S. (2008). Effect of citric acid and acetic acid on the performance of broilers. Journal of the Bangladesh Agricultural University. 6: 315-320.

Islam, K.M.S. (2012). Use of citric acid in broiler diets. World's Poultry Science Journal. 68: 104-118.

Jensen, H.D., Krogfelt, K.A., Cornett, C., Hansen, S.H., Christensen, S.B. (2003). Hydrophilic carboxylic acids and iridoid glycosides in the juice of American and European cranberries (Vaccinium macrocarpon and $V$. oxycoccos), lingonberries ( $V$. vitisidaea) and blueberries (V. myrtillus). Journal of Agricultural Food Chemistry. 50: 6871-6874.

Kalafova, A., Capcarova, M., Hrncar, C., Petruska, P., Tusimova, E., Kopecky, J. and Weis, J. (2014). Metabolic effect of citric acid in broiler chickens. Journal of Microbiol Biotech Food Science. 3: 110-112.

Khan, S.H. and Iqbal, J. (2015). Recent advances in the role of organic acids in poultry nutrition. Journal of Applied Animal Research. 44: 359-369.

Kim, J.W., Kim, J.H. and Kil, D.Y. (2015). Dietary organic acids for broiler chickens: A review. Revista Colombiana de Ciencias Pecuarias. 28: 109-123.

Kopeckı, J., Hrnčár, C. and Weis, J. (2012). Effect of organic acids supplement on performance of broiler chickens. Scientific Papers Animal Science and Biotechnologies. 45: 51-54.

Lakshmi, K.V. and Sunder, G.S. (2015). Supplementation of lactic acid and citric acid in diets replacing antibiotic and its influence on broiler performance, meat yield and immune response up to 42 days of age. International Journal of Science and Research. 4: 1007-1011.

Llor, C. and Bjerrum, L. (2014). Antimicrobial resistance: Risk associated with antibiotic overuse and initiatives to reduce the problem. Therapeutic Advances in Drug Safety. 5: 229-241.

Lückstädt, C. and Mellor, S. (2011). The use of organic acids in animal nutrition, with special focus on dietary potassium diformate under European and Austral-Asian conditions. Recent Advances in Animal Nutrition-Australia. 18: 123-130.

Mansoub, N.H., Karim, R., Leila, M., Mohammad, A.M.N., Seyede, L.Z. and Mehdi, M.K. (2011). Effect of different level of butyric acid glycerides on performance and serum composition of broiler chickens. World Journal of Zoology. 6: $179-182$. 
The Effect of Citric Acid Supplementation on Growth Performance, Digestibility and Linear Body Measurement of Ross 308...

Marshall, B.M. and Levy, S.B. (2011). Food Animals and Antimicrobials: Impacts on Human Health. Clinical Microbiology Reviews. 24: 718-733.

Max, B., Salgado, J.M., Rodríguez, N., Cortés, S., Converti, A. and Domínguez, J.M. (2010). Biotechnological production of citric acid. Brazilian journal of Microbiology. 41: 862-875.

Moghadam, A.N., Pourreza, J. and Samie, A.H. (2006). Effect of different levels of citric acid on calcium and phosphorus efficiencies in broiler chicks. Pakistan Journal of Biological Science. 9: 1250-1256.

Mohammadagheri, N., Najafi, R. and Najafi, G. (2016). Effects of dietary supplementation of organic acids and phytase on performance and intestinal histomorphology of broilers. Veterinary Research Forum. 7: 189-195.

Mohammed, H.A. (2016). Effect of utilization organic acid supplement on broiler (ros-308) feeding at pre-starter and starter period breeding on basic performance parameters. International Journal of Advanced Research in Biological Sciences. 3: 76-81.

Mohammed, H.A. (2018). Effect of organic acids supplanted in drinking water during pre-starter and starter feeding phase on broiler performance. Polytechnic Journal. 8: 60-69.

Mohyla, P., Bilgili, S.F., Oyarzabal, O.A., Warf, C.C. and Kemp, G.K. (2007). Application of acidified sodium chlorite in the drinking water to control Salmonella serotype Typhimurium and Campylobacter jejuni in commercial broilers. Journal of Applied Poultry Research. 16: 45-51.

Moyane, J.N., Jideani, A.I.O. and Aiyegoro, O.A. (2013). Antibiotics usage in food-producing animals in South Africa and impact on humans: Antibiotic resistance. African Journal of Microbiology Research. 7: 2990-2997.

M'Sadeq, S.A., Wu, S., Swick, R.A. and Choct, M. (2015). Towards the control of necrotic enteritis in broiler chickens with in-feed antibiotics phasing-out worldwide. Animal Nutrition. 1: $1-11$.

Nezhad Y.E., Shivazad, M., Nazeeradl, M. and Babak, M.M.S. (2007). Influence of citric acid and microbial phytase on performance and phytate utilization in broiler chicks fed a corn-soybean meal diet. Journal of the faculty of Veterinary Medicine, University of Tehran. 61: 407-413.

Nourmohammadi, R., Hosseini, S.M. and Farhangfar, H. (2011). Effect of citric acid and microbial phytase on serum enzyme activities and plasma minerals retention in broiler chicks. African Journal of Biotechnology. 10: 13640-13650.
Nourmohammadi, R. and Khosravinia, H. (2015). Acidic stress caused by dietary administration of citric acid in broiler chickens. Archiv fuer Tierzucht. 58: 309-315.

Paiva, D. and McElroy, A. (2014). Necrotic enteritis: Applications for the poultry industry. Journal of Applied Poultry Research. 23: $557-566$.

Pelletier, C.A. and Lawless, H.T. (2003). Effect of citric acid and citric acid-sucrose mixtures on swallowing in neurogenic oropharyngeal dysphagia. Dysphagia. 18: 231-241

Pritchard, S. (2016). Life without antibiotic growth promoters- A Uk Perspective. Australian Poultry Science Symposium. 27: 206-2012.

Rahman, M.M., Kamruzzaman, M., Khatun, M.A., Aftabuzzaman, M., Siddik, A.B., Hasan, M.J., Islam, M.Z., Ripa, S.A. and Rahman, M.G. (2018). Effect of citric acid, acetic acid and their combination on growth and meat yield performance of broiler chicken. International Journal of Science and Business. 2: 624-631.

Ragab, M.S., Abdel Wahed, H.M., Omar, E.M. and Mohamed, W.H.A. (2012). Effect of adding citric and lactic acids to broiler diets different in their protein content on productive performance, bacterial count and some blood parameters. Egyptian journal of Nutrition and Feeds. 15: 613-629.

Shah, S.Z.H., Afzal, M. and Fatima, M. (2018). Prospects of using citric acid as poultry feed supplements. JAPS: Journal of Animal and Plant Sciences. 28 (5).

Samanta, S., Haldar, S. Ghosh, T. K. (2010). Comparative efficacy of an organic acid blend and bacitracin methylene disalicylate as growth promoters in broiler chickens: effects on performance, gut histology and small intestinal milieu. Veterinary Medicine Int. 2010: 645150. doi: $10.4061 / 2010 / 645150$.

Shen, H.F., Han, C.W. and Du-Bing, W. (2005). Effect of citric acid on production performance of Three Yellow chicken. China-Poultry. 27: 14-15.

Vargas R.L., Herrera, H.J., Morales, B.E., Suarez, O.M.E., Gonzater A.M. and Garcia, B.C. (2002). Citric acid and microbial phytase relative to production performance and phosphorus, calcium and nitrogen excretion in laying hens. TechnicaPecuaria Mexico. 40: 169-180.

Waseem Mirza, M., Rehman, Z.U. and Mukhtar, N. (2016). Use of organic acids as potential feed additives in poultry production. Journal of World's Poultry Research. 6: 105-116. 